Tropical Journal of Pharmaceutical Research November 2014; 13 (11): 1889-1898

ISSN: $1596-5996$ (print); 1596-9827 (electronic)

(c) Pharmacotherapy Group, Faculty of Pharmacy, University of Benin, Benin City, 300001 Nigeria.

All rights reserved.

Available online at http://www.tjpr.org

Original Research Article

http://dx.doi.org/10.4314/tjpr.v13i11.17

\title{
Gastroprotective Activity and Mechanisms of Action of Bauhinia purpurea Linn (Leguminoseae) Leaf Methanol Extract
}

\author{
MFF Kamarolzaman ${ }^{4}$, F Yahya ${ }^{4}$, SS Mamat ${ }^{4}$, KF Jakius ${ }^{4}$, ND Mahmood ${ }^{4}$, MS \\ Shahril $^{4}$, N Mohtarrudin ${ }^{3}$, Z Suhaili ${ }^{2}$ and ZA Zakaria ${ }^{1 *}$ \\ ${ }^{1}$ Halal Product Research Institute, Universiti Putra Malaysia, 43400 UPM Serdang, Selangor, ${ }^{2}$ Department of Animal Science, \\ Faculty of Agriculture and Biotechnology, Universiti Sultan Zainal Abidin, Gong Badak Campus, 20300 Kuala Terengganu, \\ Terengganu, ${ }^{3}$ Department of Pathology, ${ }^{4}$ Department of Biomedical Science, Faculty of Medicine and Health Sciences, \\ Universiti Putra Malaysia, 43400 UPM Serdang, Selangor, Malaysia
}

*For correspondence: Email: zaz@upm.edu.my; Tel: 603-89472654; Fax: 603-89436178

Received: 30 January 2014

Revised accepted: 29 September 2014

\begin{abstract}
Purpose: To determine the gastroprotective activity and mechanisms of protection of the methanol extract of Bauhinia purpurea leaves (MEBP) using ethanol-induced gastric ulcer model.

Methods: Male Sprague Dawley rats $(n=6)$ were administered orally with $10 \%$ DMSO, $100 \mathrm{mg} / \mathrm{kg}$ ranitidine or MEBP $(50,250$ and $500 \mathrm{mg} / \mathrm{kg}$ ) daily for 7 consecutive days prior to subjection to the ethanol-induced gastric ulcer assay. The mechanisms of gastroprotection were determined based on: i) antisecretory activity via pylorus ligation assay; ii) the role of nitric oxide (NO) and sulfhydryl group via pre-treatment of MEBP-treated rats with the respective $N$-nitro-L-arginine methyl ester (L-NAME) or carbenoxolone (CBX) followed by the ethanol-induced assay; and iii) antioxidant activity using superoxide anion radical scavenging assay and, oxygen radical absorbance capacity (ORAC) assay. Ranitidine $(100 \mathrm{mg} / \mathrm{kg})$ was used as the reference drug. .

Results: MEBP exhibited a significant $(p<0.05)$ and dose-dependent gastroprotective activity against ethanol-induced gastric ulcer with ulcer formation ranging between 0 and $74 \%$ (indicated by decrease in ulcer area from 21.3 to $5.5 \mathrm{~mm}^{2}$ ). The macroscopic observation was in line with the microscopic findings and further supported by the histological scores suggesting the antiulcer potential of MEBP. $M E B P$ also significantly $(p<0.05)$ reduced volume gastric juice, as well as its free and total acidity while increasing its $\mathrm{pH}$. Moreover, this activity was significantly $(p<0.05)$ modulated in the presence of sulfhydryl group, but not NO. The extract also exhibited significant $(p<0.05)$ antioxidant activity. Conclusion: MEBP exerts gastroprotective activity partly via its antisecretory and antioxidant activities, as well as by modulation of sulfhydryl group, but not NO action.
\end{abstract}

Keywords: Bauhinia purpurea, Gastroprotective activity, Gastric ulcer, Sulfhydryl group, Anti-secretory activity, Antioxidant

Tropical Journal of Pharmaceutical Research is indexed by Science Citation Index (SciSearch), Scopus, International Pharmaceutical Abstract, Chemical Abstracts, Embase, Index Copernicus, EBSCO, African Index Medicus, JournalSeek, Journal Citation Reports/Science Edition, Directory of Open Access Journals (DOAJ), African Journal Online, Bioline International, Open-J-Gate and Pharmacy Abstracts

\section{INTRODUCTION}

Peptic ulcer affects approximately $10 \%$ of the world's population [1]. According to Hoogerwerf and Pasricha [2], reduction in gastric acid production, as well as reinforcement of gastric mucosal protection are the major approaches for therapy of peptic ulcer disease.

One of the plants in Malaysia being currently investigated for its gastroprotective effect in our laboratory is Bauhinia purpurea L (family 
Leguminoseae). B. purpurea, which has no medicinal uses in Malay traditional culture has been used in Indian, Pakistani and Sri Lankan folklore medicine to treat various ailments, including ulcers. Interestingly, the plant is also inserted in several formulation of ayurvedic medicine [3]. Scientifically, the plant has shown evidence of anti-inflammatory activity [3].

Hence, the objective of this study was to evaluate the gastroprotective potential of the methano; extract of $B$. purpurea leaves and to determine the gastroprotective mechanisms involved using various animal models.

\section{EXPERIMENTAL}

\section{Chemicals}

The chemicals used in this study were of analytical grade and their solutions were prepared immediately before use, where applicable. The drugs and chemicals were: Ranitidine (Sigma Aldrich, USA), indomethacin (Sigma-Aldrich), absolute ethanol (Fischer Scientific, USA), N-ethylmaleimide (NEM) (Sigma-Aldrich, USA), N-omega-nitro-L-arginine methyl ester (L-NAME) (Sigma-Aldrich, USA), Larginine (Sigma-Aldrich, USA), carbenoxolone (CBX) (Sigma-Aldrich, USA) and diethyl ether (Fischer Scientific, USA).

\section{Experimental animals}

Adult male Sprague-Dawley rats weighting 180 $220 \mathrm{~g}$ were procured from the animal house of Faculty of Medicine and Health Science, Universiti Putra Malaysia (UPM), Malaysia. The rats were handled in accordance with the criteria outlined in the Guide for Care and Use of Laboratory Animals [5] adopted by the current UPM guidelines for the care of laboratory animals and the ethical guidelines for investigations of experimental pain in conscious animals. The animals kept under room temperature $\left(27 \pm 2{ }^{\circ} \mathrm{C} ; 70-80 \%\right.$ humidity; $12 \mathrm{~h}$ light/dark cycle) in the Animal Holding Unit, UPM. They were supplied with food and water ad libitum until $48 \mathrm{~h}$ prior to the experiment wherein the rats were deprived of food but allowed access to water. Ethical approval (ref. no.: UPM/FPSK/PADS/BR-UUH/00451) was obtained from the Animal Care and Use Committee (ACUC), Faculty of Medicine and Health Sciences, UPM. All experiments were conducted between 09.30 and $18.30 \mathrm{~h}$ to minimize the effects of environmental changes.
Collection of plant material and preparation of methanol extract

The leaves of $B$. purpurea were collected around UPM campus, Serdang, Selangor, Malaysia and identified by Dr. Shamsul Khamis, a botanist at the Institute of Biosciences (IBS), UPM, Malaysia. A voucher specimen (no. SK 1985/11) was deposited at the Herbarium of the Laboratory of Natural Products, IBS, UPM, Malaysia.

Extraction of the leaves was carried out according to previous methods described by Yahya et al [4] to obtain the methanol extract.

The air-dried powder of $B$. purpurea leaves was macerated using methanol in the ratio of 1:20 $(w / v)$ for 72 hours. The supernatant was collected and filtered successively using cloth filter, cotton wool and Whatman No. 1 filter papers. The residue was subjected to similar extraction process for another two times and the supernatant obtained from these processes were pooled together and then evaporated at $40{ }^{\circ} \mathrm{C}$ under reduced pressure (204 mbar) using a vacuum rotary evaporator (Buchi Rotavapor ${ }^{\circledR}$ R210/215, Switzerland).

\section{Phytochemical screening and HPLC analysis}

Phytochemical screening of dried leaves of $B$. purpurea and MEBP was performed according to standard screening tests and conventional protocols as described below [4]. The phytochemical analysis was performed to detect alkaloids, flavonoids, triterpenes, tannins, saponins and steroids, based on $5.0 \mathrm{~g}$ of dried powder material and $100 \mathrm{mg}$ of extract.

\section{i) Alkaloids test:}

Samples were soaked in chloroform followed by addition of ammoniacal chloroform. The mixture was then treated with sulphuric acid $10 \%$ and further tested with Mayer's reagent. Formation of white precipitates indicates the presence of alkaloids.

\section{ii) Flavanoids test:}

The methanolic extract of samples were dissolved in ether and shaken in $10 \%$ ammonia solution. Formation of yellow colour in ammonia layer indicates the presence of flavonoids.

\section{iii) Triterpenes/Steroids Test:}

The methanolic extract of sample was analysed using Liebermann-Buchard reagent. The extract 
was mixed with few drops of acetic anhydride, boiled and cooled. Concentrated sulphuric acid was then added from the sides of the test tube and observed for the formation of a brown ring at the junction of two layers. Green coloration of the upper layer and the formation of deep red color in the lower layer would indicate a positive test for steroids and triterpenoids, respectively.

\section{iv) Tannins and polyphenolic compounds test}

The methanolic extract of samples was mixed with $1 \%$ ferric solution. Formation of blue black colour indicates the presence of hydrolysable tannins, while brownish-green indicates that of condensed tannins.

\section{v) Saponins test}

The methanolic extract of samples was mixed with distilled water in a test tube. Formation of stable froth for at least $15 \mathrm{~min}$ indicates the presence of saponins.

The HPLC analysis of MEBP was performed according to a previous report [4]. Briefly, $10 \mathrm{mg}$ of MEBP was dissolved in $1 \mathrm{ml}$ methanol and then filtered through the membrane filter (pore size $0.45 \mu \mathrm{m})$. A Waters Delta 600 with 600 Controller and Waters 2996 Photodiode Array (Milford, MA, USA) equipped with an autosampler, online degasser and column heater was used to analyze the filtered sample. Data was evaluated and processed using the installed Millenium 32 Software (Waters Product). The filtered samples were separated at $27{ }^{\circ} \mathrm{C}$ on a minibore Phenomenex Luna $5 \mu \mathrm{m}$ C18 column (dimensions $250 \times 4.60 \mathrm{~mm}$ ) using a one-step linear gradient. The solvents were (A) $0.1 \%$ aqueous formic acid and (B) acetonitrile and the elution system was as follows: Initial conditions were $85 \%$ A and $15 \%$ B with a linear gradient reaching $25 \% \mathrm{~B}$ at $\mathrm{t}=12 \mathrm{~min}$. This was maintained for $10 \mathrm{~min}$ after which the programmed returned to the initial solvent composition at $\mathrm{t}=25 \mathrm{~min}$ and continued for 10 $\mathrm{min}$. The flow rate used was $1.0 \mathrm{ml} / \mathrm{min}$ and the injection volume was $10 \mu \mathrm{l}$. The HPLC was monitored at 254 and $366 \mathrm{~nm}$.

\section{Antiulcer assays}

\section{Ethanol-induced gastric ulcer model}

The in vivo antiulcer activity of MEBP was evaluated against ethanol-induced gastric ulcer in Sprague Dawley rats as described by Zabidi et al [6]. Briefly, the animals were divided into 6 groups $(n=6)$ as given below:
- Group I: normal control, received orally $10 \%$ dimethyl sulfoxide (DMSO) and induced with $10 \%$ DMSO.

- Group II: negative control, received orally 10 $\%$ DMSO and induced with ethanol.

- Group III: positive control, received orally 100 $\mathrm{mg} / \mathrm{kg}$ of ranitidine (standard drug) and induced with ethanol.

- Group IV: received orally $50 \mathrm{mg} / \mathrm{kg}$ MEBP and induced with ethanol.

- Group V: received orally $250 \mathrm{mg} / \mathrm{kg}$ MEBP and induced with ethanol.

- Group VI: received orally $500 \mathrm{mg} / \mathrm{kg}$ MEBP and ulcer was induced with ethanol.

The $48 \mathrm{~h}$ fasted-rats received orally the vehicle (10 \% DMSO), ranitidine or MEBP for 7 consecutive days. One hour after the administration of test solutions on Day 7th, 5 $\mathrm{mL} / \mathrm{kg}$ absolute ethanol was administered orally and left for $1 \mathrm{~h}$. One hour later, the ethanolinduced rats were anesthetized using diethyl ether and then euthanized by cervical dislocation. The stomachs were removed and opened along the greater curvature. All the stomachs were gently rinsed with water to remove the gastric contents and blood clots prior to the macroscopic analysis.

\section{Macroscopic and microscopic assessments}

Macroscopic and microscopic assessments of the collected stomach were carried out as described in details by Zabidi et al [6]. Briefly, after the identification of ulcer areas, the length of ulcer was calculated and the number of ulcer spots were considered equivalent to $1 \mathrm{~mm}^{2}$ of ulcer. The ulcer area (UA) in $\mathrm{mm}^{2}$ was determined as the total sum of gastric lesions for each stomach in the group. The protection percentage (\%) was calculated using Eq 1.

Inhibition $(\%)=\left\{\left(\mathrm{UA}_{\mathrm{c}}-\mathrm{UA}_{\mathrm{t}}\right) / \mathrm{UA}_{\mathrm{c}}\right\} 100 \ldots \ldots(1)$

where $U A_{c}$ - ulcer area of the control group and $\mathrm{UA}_{\mathrm{t}}=$ ulcer area of the treatment group

In the microscopic investigation, the gastric mucosa was examined for ulcers using magnifying glass and, the number and severity of ulcer formation, in comparison to the control group, were scored according to the scoring system described by Gupta et al [7].

\section{Pyloric ligation-induced gastric ulcer}

Pylorus ligation was performed according to the method of Shay et al [8], with slight modifications. This assay was performed $30 \mathrm{~min}$ after the oral administration of the test solutions 
(i.e., $10 \%$ DMSO (negative control), $100 \mathrm{mg} / \mathrm{kg}$ ranitidine (positive control) and MEBP $(50,250$ and $500 \mathrm{mg} / \mathrm{kg})$ ). The abdomen of each rat, which was under diethyl ether-induced light anesthesia, was opened without damaging any blood supply to allow pylorus ligation. Following pylorus ligation, the abdomen was closed using sutures and each animal was allowed to recuperate for $4 \mathrm{~h}$, at the end of which the animals were anesthetized using diethyl ether and then euthanized by cervical dislocation. Measurements of $\mathrm{pH}$, volume and, total and free acidity of the gastric secretion were performed as described by Hisam et al [9]. Briefly, the abdomen was opened and a ligature was placed around the esophagus junction. The stomachs were removed and the content was measured before drained into a centrifuge tube and subjected to centrifugation at $3000 \mathrm{rpm}$ for 10 min. The $\mathrm{pH}$ of the gastric secretion was recorded with a $\mathrm{pH}$ meter. The total acidity of the gastric secretion was determined by titration with $0.01 \mathrm{~N} \mathrm{NaOH}$ and phenolphthalein was used as an indicator. Total acidity was expressed as $\mathrm{meq} / \mathrm{L}$ according to $\mathrm{Eq} 2$.

$\mathrm{n} \times 0.01 \times 36.45 \times 1000$

where $\mathrm{n}$ is the volume of $\mathrm{NaOH}$ quantified, 36.45 is the molecular weight of $\mathrm{NaOH}, 0.01$ is normality of $\mathrm{NaOH}$ and 1000 is the factor represented in litre.

Gastric wall mucus content was determined according to the procedure described by Corne et al [10] with slight modifications. Briefly, the stomach was opened along the greater curvature, weighed and immersed in $10 \mathrm{ml}$ of $0.1 \%$ Alcian blue in $0.16 \mathrm{M}$ sucrose $/ 0.05 \mathrm{M}$ sodium acetate, $\mathrm{pH} 5.8$ for $2 \mathrm{~h}$. Then, the excessive dye was removed by two successive rinses of $0.25 \mathrm{M}$ sucrose solution for $15 \mathrm{~min}$ and $45 \mathrm{~min}$. The remaining dye that complexed with the gastric mucus were then extracted with $0.5 \mathrm{M}$ $\mathrm{MgCl}_{2}$ over $2 \mathrm{~h}$ and shaken intermittently every $30 \mathrm{~min}$. The blue extract was then shaken vigorously and the optical density was measured using a spectrophotometer at $580 \mathrm{~nm}$. The quantity of Alcian blue extract per gram of wet stomach was calculated from the standard curve.

\section{Ethanol-induced gastric mucosal lesion in L- NAME pre-treated rats}

The involvement of endogenous nitric oxide in modulating MEBP-induced antiulcer activity was determined according to the method of Andreo et al [11], with slight modifications. The animals were pre-treated with saline or (L-NAME) (70 $\mathrm{mg} / \mathrm{kg}$ ) intraperitoneally (i.p.) and $30 \mathrm{~min}$ later, the animals received vehicle ( $8 \%$ Tween 80 ), $100 \mathrm{mg} / \mathrm{kg}$ carbenoloxone or $500 \mathrm{mg} / \mathrm{kg}$ MEBP (p.o.). One hour after administration of the test solutions, gastric ulcer was induced using 5 $\mathrm{mL} / \mathrm{kg}$ absolute ethanol in all groups. On the other hand, L-arginine $(200 \mathrm{mg} / \mathrm{kg})$ was administered $30 \mathrm{~min}$ after saline or L-NAME treatment, and this was followed 30 min later by ethanol administration. All the rats were sacrificed $1 \mathrm{~h}$ after the administration of ethanol by exposure to diethyl ether. The stomach was removed and gastric damage was determined as described above.

\section{Ethanol-induced gastric mucosal lesion in NEM pre-treated rats}

To investigate on the involvement of sulfhydryl $(\mathrm{SH})$ group in the modulation of MEBP-induced antiulcer activity, the procedures described by Andreo et al [11] were adopted with slight modifications. The rats were randomly divided into 6 groups $(n=6)$ and fasted for $24 \mathrm{~h}$ but allowed free access to water. The experiment started with pre-treatment (i.p.) with saline or NEM $(10 \mathrm{mg} / \mathrm{kg})$, a SH- blocker. Thirty min after the pre-treatment regimen, the rats were administered (p.o.) with vehicle (8\% Tween 80$)$, $100 \mathrm{mg} / \mathrm{kg}$ carbenoloxone or $500 \mathrm{mg} / \mathrm{kg}$ MEBP followed $1 \mathrm{~h}$ later by $5 \mathrm{~mL} / \mathrm{kg}$ ethanol-induced gastric ulceration. All the animals were sacrificed $1 \mathrm{~h}$ after receiving ethanol by exposure to diethyl ether. The stomach was removed and gastric damage was determined as described above.

\section{Antioxidant assays}

The antioxidant activity of MEBP was determined using superoxide anion radical scavenging assay [13] and oxygen radical absorbance capacity (ORAC) assay [14].

\section{Superoxide anion radical scavenging}

Measurement of superoxide anion radicals scavenging activity of MEBP was based on the method described by Liu et al [15]. Superoxide radicals are generated in PMS - NADH systems by oxidation of $\mathrm{NADH}$ and assayed by the reduction of NBT. In these experiments, the superoxide radicals were generated in $3 \mathrm{ml}$ of Tris- $\mathrm{HCl}$ buffer $(16 \mathrm{mM}, \mathrm{pH} 8.0)$ containing $1 \mathrm{ml}$ of NBT $(50 \mu \mathrm{M}), 1 \mathrm{ml}$ NADH $(78 \mu \mathrm{M})$ and MEMM $(200 \mu \mathrm{g} / \mathrm{ml})$. The reaction was started by adding $1 \mathrm{ml}$ of PMS solution $(10 \mu \mathrm{M})$ to the mixture. The reaction mixture was incubated at $25{ }^{\circ} \mathrm{C}$ for 5 min; the absorbance was read at $560 \mathrm{~nm}$ using a spectrophotometer (Schimadzu UV-Vis 1700) against blank samples using L-ascorbic acid as a control. The decreased absorbance of the 
reaction mixture indicated increasing superoxide anion scavenging activity. Inhibition of superoxide anion generation was calculated using Eq 3.

Inhibition $(\%)=\left\{\left(A_{0}-A_{1}\right) / A_{0}\right\} 100$

where $A_{0}$ is the absorbance of the control ( $L$ ascorbic acid), and $A_{1}$ is absorbance in the presence of MEBP or standard.

\section{Oxygen radical absorbance capacity (ORAC)}

A microplate fluorescence reader with an excitation wavelength of $540 \mathrm{~nm}$ and an emission wavelength of $565 \mathrm{~nm}$ was used [16]. The $75 \mu \mathrm{L}$ AAPH (160 mM), $150 \mu \mathrm{L} \beta$-PE (68 mg/L), and 20 $\mu \mathrm{M}$ 6-hydroxy-2,5,7,8-tetra-methylchroman-2carboxylic acid (Trolox) were prepared in $75 \mathrm{mM}$ phosphate buffer ( $\mathrm{pH}$ 7.0). AAPH and Trolox were prepared fresh while $\beta$-PE was prepared earlier and kept at $4^{\circ} \mathrm{C}$ in dark condition. Trolox standard was diluted in the PBS to give $20 \mu \mathrm{M}$ working solutions. To the 96-well plates (Nunc, Thermo Scientific) $150 \mu \mathrm{L}$ of $\beta$-PE was added followed by $25 \mu \mathrm{L}$ of trolox, buffer (blank), or 150 $\mu \mathrm{L}$ MEBP $(200 \mu \mathrm{g} / \mathrm{ml})$, and lastly, $25 \mu \mathrm{L}$ AAPH was injected into the microplate reader via injector. ORAC values were calculated based on net area under the curve (AUC) obtained by subtracting the AUC of the blank from that of MEBP and compared to the Trolox standard curve. The antioxidant capacity (ORAC) related to trolox was calculated as in Eq 4.

ORAC value $=\left\{\left(\mathrm{AUC}_{\text {sample }}-\mathrm{AUC}_{\text {blank }}\right) /\left(\mathrm{AUC}_{\text {Trolox }}{ }^{-}\right.\right.$ $\left.\left.A \cup C_{\text {blank }}\right)\right\} \times\{$ (molarity of Trolox/molarity of sample)

\section{Statistical analysis}

All the data are presented as mean \pm standard deviation (SD) and were analyzed by analysis of variance (ANOVA). Differences between the groups were determined using Dunnet post-hoc test. Significant difference between treatments was set at $p<0.05$.

\section{RESULTS}

\section{Phytochemical profiles of the plant and extract}

Saponins, flavonoids, tannins and polyphenolic compounds, triterpenes and steroids, but not alkaloids, were detected in both the leaf of $B$. purpurea and MEBP (Table 1).
The HPLC profile of MEBP showed that $366 \mathrm{~nm}$ was the optimum wavelength at which separation of 4 major peaks (P1, P2, P3, and P4) were observed in the chromatogram and they occurred at retention time (RT) of 2.953, 18.40, 19.61 and $20.16 \mathrm{~min}$, respectively. Further analysis indicate that the four peaks showed $\lambda$ max values in the region of 193.2 - 268.5, 203.7 - 350.6, 228.4 342.2 and 203.7 - $350.6 \mathrm{~nm}$, respectively.

Table 1: Phytochemical profiles of $B$. purpurea leaf (BP) and its extract (MEBP)

\begin{tabular}{lcc}
\hline $\begin{array}{l}\text { Phytochemical } \\
\text { constituent }\end{array}$ & Sample & Result \\
\hline Alkaloid & BP & - \\
& MEBP & - \\
Saponin & BP & $1+$ \\
& MEBP & $1+$ \\
Flavonoid & BP & $1+$ \\
& MEBP & $1+$ \\
Tannins \& polyphenolic & BP & $1+$ \\
& MEBP & $1+$ \\
Triterpene & BP & $3+$ \\
& MEBP & $1+$ \\
Steroid & BP & $3+$ \\
& MEBP & $2+$ \\
\hline
\end{tabular}

For saponins, $+=1-2 \mathrm{~cm}$ froth; $++=2-3 \mathrm{~cm}$ froth; +++ $=>3 \mathrm{~cm}$ froth; For flavonoids, tannins, triterpenes and steroids -+- weak colour; $++=$ mild colour; $+++=$ strong colour; For akalioids; + = negligible amount of precipitate; $++=$ weak precipitate; $+++=$ strong precipitate

\section{Gastroprotective activity against ethanol- induced gastric ulcer}

Oral administration of ethanol caused gastric ulcer formation in the stomach which severely affected the mucosal layer when pre-treated only with $10 \%$ DMSO (negative control). Pretreatment with 250 and $500 \mathrm{mg} / \mathrm{kg}$ MEBP demonstrated significant $(p<0.05)$ reduction in gastric injury in a dose-dependent manner. Gastroprotective activity was recorded as 54.47 and $73.17 \%$, respectively (Table 2). Morphological examination (Figure 1A-1F)

Table 2: Effect of various doses of MEBP and ranitidine on ethanol-induced gastric ulcer in rats

\begin{tabular}{|c|c|c|}
\hline $\begin{array}{l}\text { Pre- } \\
\text { treatment }\end{array}$ & $\begin{array}{c}\text { Dose } \\
\text { (mg / kg) }\end{array}$ & $\begin{array}{c}\text { Ulcer area } \\
\left(\mathrm{mm}^{2}\right)\end{array}$ \\
\hline $10 \%$ DMSO & - & $20.50 \pm 3.24$ \\
\hline Ranitidine & $\begin{array}{c}100 \\
50\end{array}$ & $\begin{array}{l}5.00 \pm 1.21^{\text {** }} \\
21.33 \pm 2.14\end{array}$ \\
\hline MEBP & $\begin{array}{l}250 \\
500\end{array}$ & $\begin{array}{c}9.33 \pm 1.89^{*} \\
5.50 \pm 2.11^{* *}\end{array}$ \\
\hline
\end{tabular}

Trop J Pharm Res, November 2014; 13(11):1893 
showed severe haemorrhagic red bands (ulcer streaks) on the mucosal layer of the stomach in negative control group (Fig. 1B) in comparison to the normal group (Fig. 1A). The microscopic analysis shows that ethanol induced the formation of mucosa erosion, hemorrhage and edema, which were inhibited following pretreatment with MEBP (Figure 2A-F). The histological scoring is shown in Table 3.

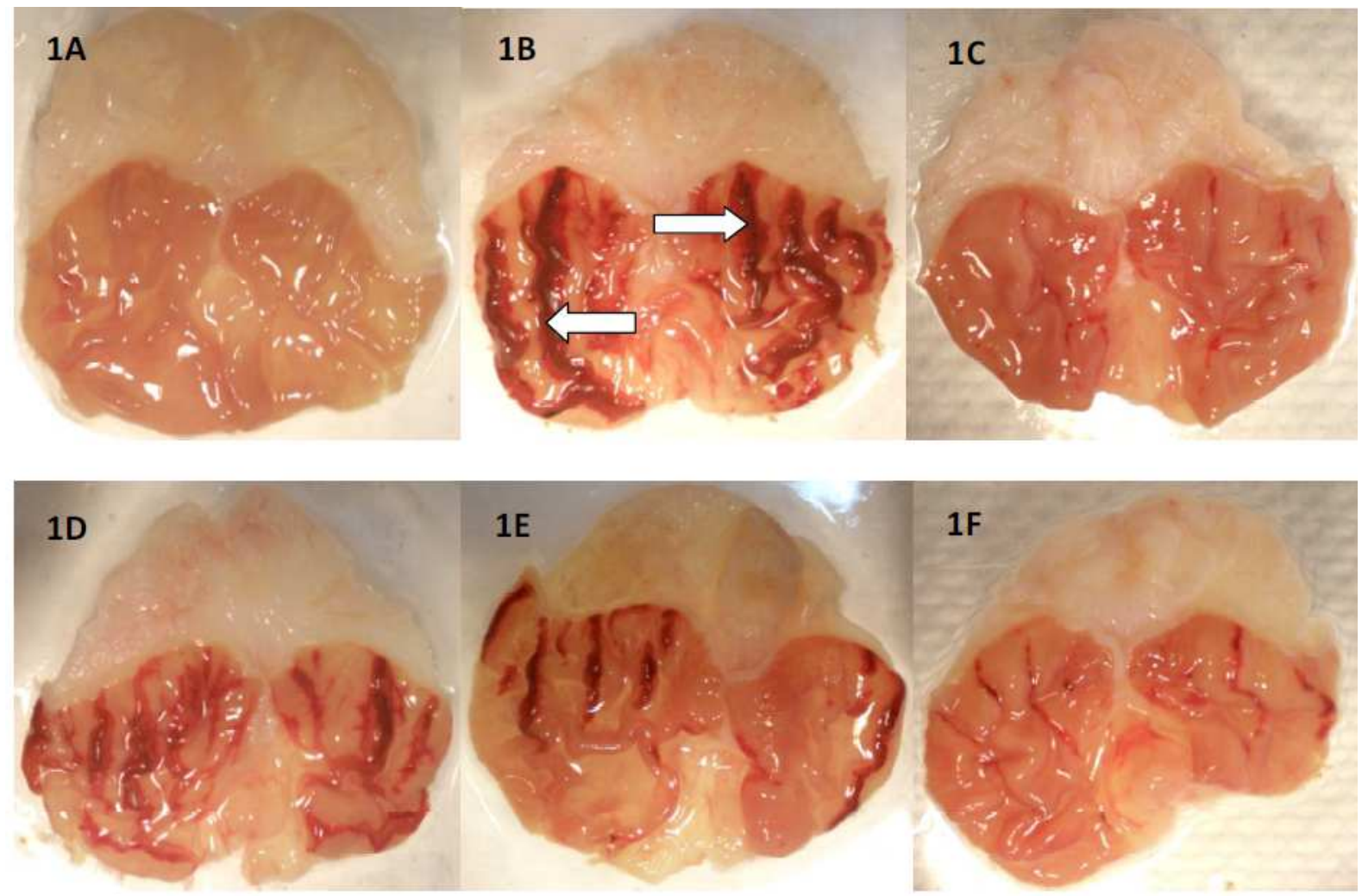

Figure 1: The macroscopic features of the rats' ethanol-induced gastric ulcer stomach following treatment with MEBP, at the concentrations of 50,250 and $500 \mathrm{mg} / \mathrm{kg}$, or $100 \mathrm{mg} / \mathrm{kg}$ ranitidine. 1A) the normal untreated stomach, 1B) the stomach induced with absolute ethanol $(5 \mathrm{ml} / \mathrm{kg})$ and pre-treated with $10 \%$ DMSO showed streak of ulcer formation (shown by arrows), 1C) ) the stomach induced with absolute ethanol (5 $\mathrm{ml} / \mathrm{kg})$ and pretreated $100 \mathrm{mg} / \mathrm{kg}$ ranitidine; 1D-1F) the stomach induced with absolute ethanol $(5 \mathrm{ml} / \mathrm{kg})$ and pre-treated with $50 \mathrm{mg} / \mathrm{kg}$ MEBP, $250 \mathrm{mg} / \mathrm{kg}$ MEBP or $500 \mathrm{mg} / \mathrm{kg}$ MEBP, respectively. (x40 magnification)

Table 3: Histopathological features of ethanol-induced gastric ulcer in rats treated with MEBP

\begin{tabular}{|c|c|c|c|c|}
\hline Pre-treatment & $\begin{array}{l}\text { Architecture of the } \\
\text { mucosa }\end{array}$ & Haemorrhage & $\begin{array}{c}\text { Inflammatory } \\
\text { exudate }\end{array}$ & Oedema \\
\hline $10 \%$ DMSO & ++ & +++ & + & ++ \\
\hline 100 mg / kg Ranitidine & + & ++ & - & + \\
\hline 50 mg / kg MEBP & ++ & ++ & - & ++ \\
\hline 250 mg / kg MEBP & + & + & - & + \\
\hline 500 mg / kg MEBP & + & + & - & + \\
\hline
\end{tabular}

The severity of various features of ethanol-induced gastric ulcer were evaluated according to the following scoring format: $-=$ normal; $+=$ mild effect $;++=$ moderate effect $;+++=$ severe effect

\section{Effect of MEBP on pylorus ligation-induced gastric ulcer}

Table 4 shows the results obtained after pretreatment of rats with MEBP against the pyloric ligation assay. The MEBP, at all doses tested, caused significant $(p<0.05)$ decreased in the volume of gastric juice formation and free acidity of the gastric juice. Moreover, only 250 and 500 $\mathrm{mg} / \mathrm{kg}$ MEBP significantly $(p<0.05)$ increase the $\mathrm{pH}$ of the gastric juice while reducing the total acidity of the gastric juice. Ranitidine also significantly $(p<0.05)$ reduced the volume and, total- and free-acidity of the gastric juice while increasing the $\mathrm{pH}$ of the juice. In addition, the MEBP also caused significant $(p<0.05)$ increase in the gastric wall mucus content (Table 5 ). 

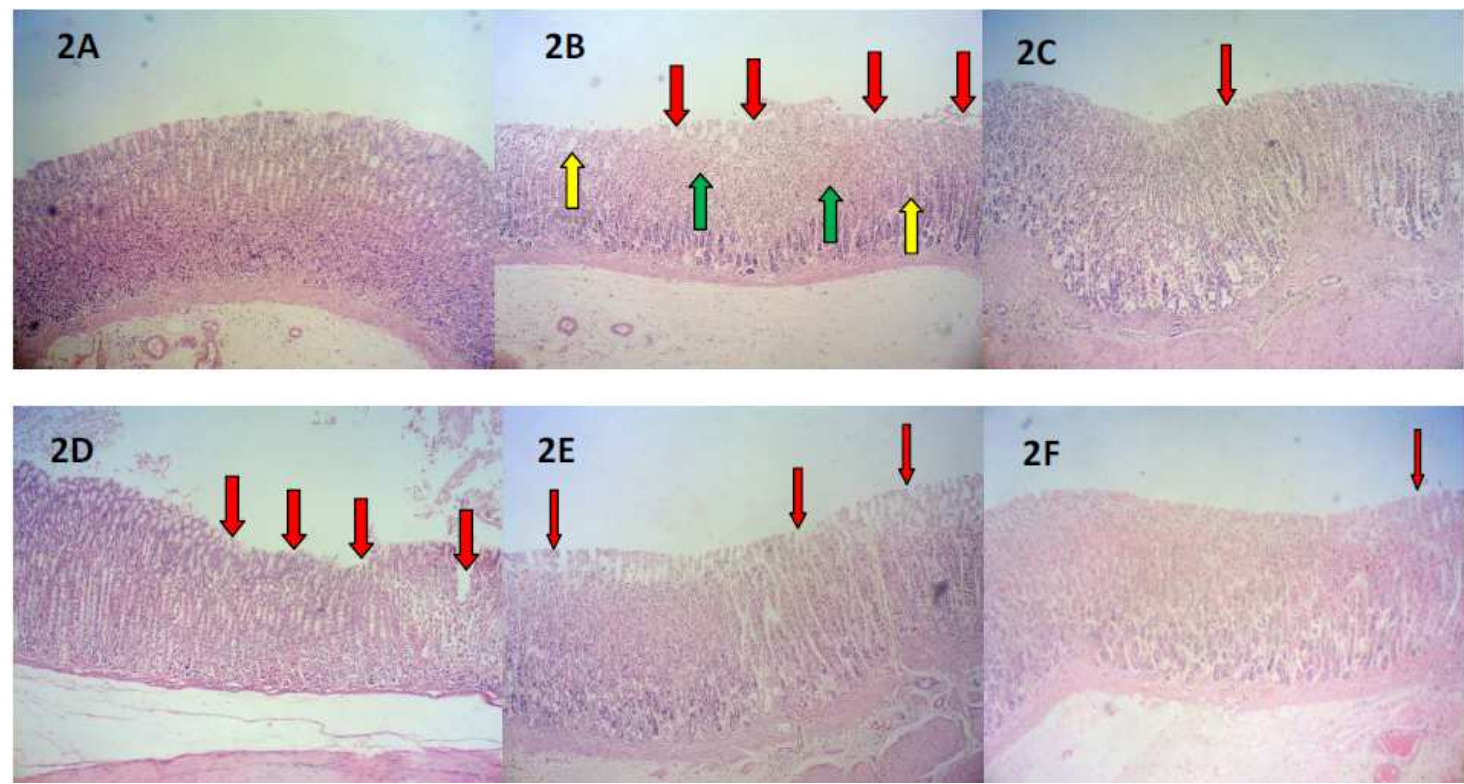

Figure 2: The microscopic findings on the rats' ethanol-induced gastric ulcer stomach following treatment with MEBP, at the concentrations of 50,250 and $500 \mathrm{mg} / \mathrm{kg}$, or $100 \mathrm{mg} / \mathrm{kg}$ ranitidine. $2 \mathrm{~A}$ ) the normal untreated stomach, $2 \mathrm{~B})$ the stomach induced with absolute ethanol $(5 \mathrm{ml} / \mathrm{kg})$ and pre-treated with $10 \%$ DMSO shows the presence of severe mucosa erosion (indicated by red-coloured arrow; edema (indicated by yellow-coloured arrow; and hemorrhage (indicated by green-coloured arrow; $2 \mathrm{C}$ ) ) the stomach induced with absolute ethanol (5 $\mathrm{ml} / \mathrm{kg}$ ) and pre-treated $100 \mathrm{mg} / \mathrm{kg}$ ranitidine indicated almost no ulcer formation; 2D-2F) the stomach induced with absolute ethanol $(5 \mathrm{ml} / \mathrm{kg}$ ) and pre-treated with $50 \mathrm{mg} / \mathrm{kg}$ MEBP, $250 \mathrm{mg} / \mathrm{kg}$ MEBP or $500 \mathrm{mg} / \mathrm{kg}$ MEBP, respectively. The mucosa erosion reduced as the concentration of MEBP increases as indicated by reduce in the thickness of red arrow (x40 magnification)

Table 4: Effect of MEBP on the biochemical parameters of gastric juice obtained from pylorus-ligature rats

\begin{tabular}{|c|c|c|c|c|c|}
\hline Pre-treatment & $\begin{array}{l}\text { Dose } \\
(\mathrm{mg} / \mathrm{kg})\end{array}$ & $\begin{array}{l}\text { Gastric juice } \\
(\mathrm{ml})\end{array}$ & $\mathrm{pH}$ & $\begin{array}{l}\text { Total acidity } \\
(\mathrm{mEq} . / \mathrm{L} / 4 \mathrm{~h})\end{array}$ & $\begin{array}{l}\text { Free acidity } \\
\text { (mEq./L/4 h) }\end{array}$ \\
\hline $10 \%$ DMSO & - & $5.83 \pm 1.01$ & $1.36 \pm 0.04$ & $543.00 \pm 380.40$ & $4367.00 \pm 573.30$ \\
\hline \multirow[t]{2}{*}{ Ranitidine } & 100 & $1.63 \pm 0.30^{\star * *}$ & $4.18 \pm 0.81^{\text {***}}$ & $143.00 \pm 92.15^{\star * *}$ & $1500.00 \pm 235.20^{\star * *}$ \\
\hline & 50 & $3.32 \pm 0.86^{*}$ & $2.23 \pm 0.13$ & $467.00 \pm 340.70$ & $1660.00 \pm 438.5^{\star *}$ \\
\hline \multirow[t]{2}{*}{ MEBP } & 250 & $2.18 \pm 0.63^{\star \star}$ & $3.47 \pm 0.29^{\star *}$ & $416.00 \pm 134.10^{\star \star}$ & $1180.00 \pm 504.40^{* * *}$ \\
\hline & 500 & $1.68 \pm 0.15^{\star \star \star}$ & $3.17 \pm 0.27^{\star}$ & $368.00 \pm 198.40^{\star * *}$ & $993.30 \pm 523.00^{\star \star *}$ \\
\hline
\end{tabular}

Effect of L-NAME on the gastroprotective activity of MEBP against the ethanol-induced ulcer in rats

The results obtained after pre-challenging the test solutions with distilled water $\left(\mathrm{dH}_{2} \mathrm{O}\right)$ or LNAME is shown in Table 6. Within the $10 \%$ DMSO-treated groups, the group pre-challenged with L-NAME demonstrated significant $(p<0.05)$ increase in the severity of ulcer formation when compared to the group pre-challenged with $\mathrm{dH}_{2} \mathrm{O}$. However, pre-treatment of L-NAME failed to affect the gastroprotective effect exerted by the $500 \mathrm{mg} / \mathrm{kg} \mathrm{MEBP}$ or $100 \mathrm{mg} / \mathrm{kg}$ CBX indicating lack of influences of L-NAME on MEBP or CBX.
Table 5: Effect of MEBP and ranitidine on gastric wall mucus content

\begin{tabular}{lll}
\hline Pre-treatment & $\begin{array}{l}\text { Dose, } \\
\text { (mg/kg) }\end{array}$ & $\begin{array}{l}\text { Gastric wall } \\
\text { mucus (Alcian } \\
\text { blue } \boldsymbol{\mu g} / \mathbf{g} \text { wet } \\
\text { tissue) }\end{array}$ \\
\hline $10 \%$ DMSO & - & $85.68 \pm 13.76$ \\
Ranitidine & 100 & $241.30 \pm 14.11^{\star}$ \\
& 50 & $595.10 \pm 51.55^{\star \star \star}$ \\
MEBP & 250 & $307.70 \pm 13.92^{\star *}$ \\
& 500 & $622.00 \pm 75.18^{\star \star \star}$ \\
\hline
\end{tabular}

Values are mean \pm SEM $(\mathrm{n}=6 /$ group $){ }^{*} p<0.05,{ }^{* *} p<$ $0.005,{ }^{* *} p<0.001$

\section{Effect of NEM on the gastroprotective activity of MEBP against the ethanol-induced ulcer in rats}

The results obtained after pre-challenging the test solutions with $\mathrm{dH}_{2} \mathrm{O}$ or NEM is shown in 
Table 6: Effecs of the MEBP on ethanol-induced gastric ulcer in rats pre-treated with L-NAME or NEM

\begin{tabular}{lccc}
\hline Pretreatment & $\begin{array}{c}\text { Treatment } \\
(\mathbf{p . o .})\end{array}$ & $\begin{array}{c}\text { Dose } \\
(\mathbf{m g} / \mathbf{k g})\end{array}$ & $\begin{array}{c}\text { Ulcer area } \\
\left(\mathbf{m m}^{2}\right)\end{array}$ \\
\hline Saline & $10 \%$ DMSO & - & $9.83 \pm 1.01$ \\
& MEBP & 500 & $4.17 \pm 0.48^{\mathrm{a}}$ \\
& Carbenoxolone & 100 & $3.67 \pm 0.61^{\mathrm{a}}$ \\
\hline L-NAME $(70 \mathrm{mg} / \mathrm{kg})$ & $10 \%$ DMSO & - & $30.50 \pm 3.84^{\mathrm{b}}$ \\
& MEBP & 500 & $4.50 \pm 0.67^{\mathrm{ad}}$ \\
& Carbenoxolone & 100 & $5.50 \pm 1.06^{\mathrm{ad}}$ \\
\hline NEM $(10 \mathrm{mg} / \mathrm{kg})$ & $10 \%$ DMSO & - & $13.67 \pm 2.49^{\mathrm{c}}$ \\
& MEBP & 500 & $9.00 \pm 1.65^{\mathrm{eg}}$ \\
& Carbenoxolone & 100 & $6.00 \pm 1.21^{\mathrm{gg}}$ \\
\hline
\end{tabular}

${ }^{a, b, c}$ Significantly different $(p<0.05)$ compared to the saline+10\% DMSO-treated group; ${ }^{d}$ significantly different $(p<$ 0.05) compared to L-NAME+10\% DMSO-treated group; ${ }^{e}$ significantly different $(p<0.05)$ compared to saline+MEBP-treated group; ${ }^{f}$ significantly different $(p<0.05)$ compared to saline+carbenoxolone-treated group; ${ }^{g}$ significantly different $(p<0.05)$ compared to the $(N E M+10 \% D M S O)$-treated group; values are mean $\pm S E M(n=$ 6 rats/group)

Table 6. Among the $10 \%$ DMSO-treated group, the group pre-challenged with NEM showed significantly $(p<0.05)$ severe gastric ulcer formation in comparison to the group prechallenged with $\mathrm{dH}_{2} \mathrm{O}$ indicating the important of sulfhydryl group in gastroprotection. The gastroprotective effect seen in the $500 \mathrm{mg} / \mathrm{kg}$ MEBP- or $100 \mathrm{mg} / \mathrm{kg} \mathrm{CBX-treated} \mathrm{groups} \mathrm{pre-}$ challenged with $\mathrm{dH}_{2} \mathrm{O}$ were significantly $(p<$ 0.05 ) reversed following pre-treatment with 10 $\mathrm{mg} / \mathrm{kg} \mathrm{NEM}$.

\section{Antioxidant activity of MEBP}

MEBP, at $200 \mu \mathrm{g} / \mathrm{ml}$, exerted a high antioxidant activity when assessed using the superoxide anion radical scavenging assay and ORAC assay. The percentage of antioxidant recorded through the radical scavenging assay was 78.55 $\pm 1.62 \%$. According to the standard superoxide anion radical scavenging protocol, the antioxidant activity is considered high if the percentage of antioxidant falls within the range of $71-100 \%$. Therefore, the MEBP is considered to have high antioxidant potential. Furthermore, the ORAC value of MEBP recorded via the ORAC assay was $23,060 \mu \mathrm{M}$ Trolox equivalents (TE) / $100 \mathrm{~g}$.

\section{DISCUSSION}

Ethanol-induced gastric ulcer is attributed to the direct toxic action of ethanol, reduction of the secretion of bicarbonate, and depletion of gastric wall mucus [16]. Ingestion of excess amount of ethanol causes hemorrhagic ulceration of the stomach by causing extensive damage to mucosal capillaries resulting in increased vascular permeability, oedema formation and epithelial lifting [16] either in human or experimental animals. It is plausible to suggest that the MEBP-induced gastroprotective activity involved the extract ability to reduce vascular permeability, which help to prevent capillary endothelium injury and, therefore, arachidonate metabolites release; to induce anti-inflammatory activity, which help prevent the release of various inflammatory mediators and; to induce an antioxidant activity, which help prevent lipid peroxidation and attenuate the action of free radicals.

The MEBP-exhibited gastroprotective activity seen with the pyloric ligation-induced model involves reducing the volume of gastric acid secretion, neutralizing the acidic condition of the gastric acid secretion, increasing the mucus secretion and strengthening the mucosal barrier. The release of excess amount of acid-pepsin content leads to the autodigestion of gastric mucosa while reduce in the acid-pepsin release, as seen with MEBP pretreatment, indicates the extract antiulcer potential. This statement is in line with report by Kitagawa et al [17], who earlier suggested gastric hypersecretion as the main cause of ulcer formation in the pyloric ligationinduced gastric ulcer model.

NO has been generally known to take part in the regulation of acid secretion and maintenance of gastric mucosal integrity against hyperacidity or exposure to ulcerogens. Other than that, NO has also been linked to regulation of mucus secretion, acid and alkaline secretion, prostaglandins (PGs) synthesis and gastric mucosal blood flow [18]. In the present study, the absence or reduction of $\mathrm{NO}$ level, which is due to the presence of L-NAME, failed to affect the 500 $\mathrm{mg} / \mathrm{kg} \quad$ MEBP-exhibited gastroprotection indicating the non-involvement of $\mathrm{NO}$ in the MEBP-produced gastroprotective activity. This kind of activity has been reported for several other gastroprotective compounds [19,20,21]. 
In the present study, pre-challenging NEM with $10 \%$ DMSO markedly increased the gastric lesions indicating the role of NP-SH compounds in ulcer formation. In contrast, the ability of NEM to reverse the $500 \mathrm{mg} / \mathrm{kg}$ MEBP and $100 \mathrm{mg} / \mathrm{kg}$ $\mathrm{CBX}$ antiulcer activity suggested the involvement of $\mathrm{SH}$ compounds in gastroprotection mechanisms of MEBP. Usually, the extent of gastric mucosal damage induced by ethanol is accompanied by a decrease in the concentration of mucosal NP-SH compounds. This correlation could be related to the potential of $\mathrm{SH}$-groups to bind to the free radicals, which are formed during tissue injury due to the action of ethanol, and being neutralized [22].

\section{CONCLUSION}

B. purpurea extract attenuates ethanol-induced gastric ulcer formation via various mechanisms such as antisecretory and antioxidant activities, and modulation of sulfhydryl group, but not NO action. Therefore, $B$. purpurea extract is a potential candidate for the development of pharmacological agents for the treatment of inflammation-mediated diseases. Further research is warranted to isolate the responsible bioactive compounds, and evaluate their activities and molecular mechanisms in an attempt to accurately define the structure-activity relationship of the molecular regulatory mechanisms.

\section{ACKNOWLEDGEMENT}

This study was supported by the Science Fund Research Grant (ref no. 06-01-04-SF1127) from the Ministry of Science Technology and Innovation, Malaysia (MOSTI) and the Research University Grant Scheme (ref no. 04-02-122019RU) from the Universiti Putra Malaysia, Malaysia. The authors would also like to thank Universiti Putra Malaysia for providing facilities to conduct this study.

\section{REFERENCES}

1. Zapata-Colindomethacinres JC, Zepeda-Go'mez $S$, Montañ-Loza A, Va'zquez-Ballesteros E, Villalobos $J J$, Valdovinos-Andraca $F$. The association of Helicobacter pylori infection and nonsteroidal antiinflammatory drugs in peptic ulcer disease. Can $J$ Gastroenterol 2006; 20: 277-280.

2. Hoogerwerf WA, Pasricha PJ. Agents used for control of gastric acidity and treatment of peptic ulcers and gastroesophageal reflux disease. In: Harman JG, Limbird LE, Eds. Goodman \& Gilman's The
Pharmacological Basis of Therapeutics. 10th edn, New York: McGraw-Hill; 2001; pp 1011-1012.

3. Zakaria ZA, Loo YW, Abdul Rahman NI, Abdul Ayub AH, Sulaiman MR, Hanan Kumar G. Antinociceptive, antiinflammatory and antipyretic properties of Bauhinia purpurea leaves aqueous extract in experimental animals. Med Princ Pract 2007; 16: 443-449.

4. Yahya F, Mamat SS, Kamarolzaman MFF, Seyyedan A, Jakius KF, Mahmood ND, Shahril MS, Suhaili Z, Mohtarrudin N, Susanti D, Somchit MN, Teh LK, Salleh MZ, Zakaria ZA. Hepatoprotective activity of methanolic extract of leaves of Bauhinia purpurea in paracetamol-induced hepatic damage in rats. Evid Compliment Altern Med 2013; 2013: 1-10.

5. Institute for Laboratory Animal Research. Guide for the care and use of laboratory animals, 8th edn. Washington (DC): National Academies Press, 2011.

6. Zabidi Z, Wan Zainulddin WN, Mamat SS, Shamsahal Din S, Kamisan FH, Yahya F, Ismail NA, Rodzi R, Hussain $H$, Mohtarrudin N, Somchit MN, Zakaria ZA. Antiulcer activity of methanol extract of Melastoma malabathricum leaves in rats. Med Princ Pract 2012; 21: 501-503.

7. Gupta M, Mazumder UK, Manikandan L, Bhattacharya S, Senthilkumarm GP, Suresh R. Anti-ulcer activity of ethanol extract of Terminalia pallida Brandis in Swiss albino rats. J Ethnopharmacol 2005; 97: 405-408.

8. Shay H, Komarov SA, Fels SS, Meranze D, Gruenstein $M$, Siplet H. A simple method for the uniform production of gastric ulceration in the rat. Gastroenterology 1945; 5: 43-61.

9. Abdul Hisam EE, Zakaria ZA, Mohtaruddin N, Rofiee MS, Hamid $A H$, Othman F. Antiulcer Activity of the Chloroform Extract of Bauhinia purpurea Leaf. Pharmaceut Biol 2012; 50: 1498-1507.

10. Corne SJ, Morrissey SM, Woods RJ. A Method for the quantitative estimation of gastric barrier mucous. $J$ Physiol 1974; 242: 116P-117P.

11. Andreo MA, Ballesteros KVR, Hiruma-Lima CA, Machado da Rocha LR, Souza Brito, ARM, Vilegas W. Effect of Mouriri pusa extracts on experimentally indomethacin-induced gastric lesions in rodents: Role of endogenous sulfhydryls compounds and nitric oxide in gastroprotection. J Ethnopharmacol 2006; 107: 431-441.

12. Blois MS. Antioxidant determinations by the use of a stable free radical. Nature. 1958; 181: 1199-1200.

13. Liu F, Ooi VEC, Chang ST. Free radical scavenging activities of mushroom polysaccharide extracts. Life Sci 1997; 60: 763-771.

14. Cao G, Prior RL. Measurement of oxygen radical absorbance capacity in biological samples. Methods Enzymol. 1999; 299: 50-62.

15. Singleton VL, Rossi JA. Colorimetry of total phenolics with phosphomolybdic-phosphotungstic acid reagents. Am J Enol Vitic. 1965; 16: 144-158.

16. Nordmann R. Alcohol and antioxidant systems. Alcohol and Alcoholism. 1994; 29: 513-522.

Trop J Pharm Res, November 2014; 13(11):1897 
17. Kitagawa $H$, Kurahashi $K$, Fujiwara $M$, Kohei $H$. Antiulcerogenic effect of a pyrido-benzodazepine derivative (L-S519) on experimental ulcers. Arzneim Forsch 1978; 28: 2122-2127.

18. Chandranath SI, Bastaki SM, Singh J. A comparative study on the activity of lansoprazole, omeprazole and $P D-136450$ on acidified ethanol- and indomethacininduced gastric lesions in the rat. Clin Exp Pharmacol Physiol 2002; 29: 173-180.

19. Santin JR, Lemos M, Klein-Júnior LC, Machado ID, Costa $P$, de Oliveira AP, Tilia C, de Souza JP, de Sousa JP, Bastos JK, De Andrade SF. Gastroprotective activity of essential oil of the Syzygium aromaticum and its major component eugenol in different animal models. Naunyn Schmiedebergs Arch Pharmacol 2011; 383: 149-158.
20. Silva MI, Moura BA, Neto MR, Tomé AR, Rocha NF, de Carvalho AM, Macêdo DS, Vasconcelos SM, de Sousa DP, Viana GS, de Sousa FC. Gastroprotective activity of isopulegol on experimentally induced gastric lesions in mice: investigation of possible mechanisms of action. Naunyn Schmiedebergs Arch Pharmacol 2009; 380: 233-245.

21. Bruna $P$, Siqueira J, Menezes CT, Silva JP, de Sousa DP, Batista JS. Antiulcer effect of epoxy-carvone. Revista Brasileira de Farmacognosia Brazilian J Pharmacognosy 2012; 22(1): 144-149.

22. Maity S, Vedasiromoni JR, Ganguly DK. Role of glutathione in the antiulcer effect of hot water extract of black tea (Camellia sinensis). Jpn J Pharmacol. 1998; 78: 285-292. 